\title{
KINO OPERATORÓW - FESTIWAL PLUS CAMERIMAGE 2008
}

16. Międzynarodowy Festiwal Sztuki Autorów Zdjęć Filmowych PLUS CAMERIMAGE 2008, Centrum Festiwalowe, Teatr Wielki, Łódź 29.11-06.12.2008.

Na Międzynarodowym Festiwalu Sztuki Autorów Zdjęć Filmowych Plus Camerimage miałam przyjemność gościć już po raz piąty. Camerimage jest dużą imprezą, która na siedem dni zmienia część Łodzi w centrum kultury. Czy popularnej? Myślę, że charakter festiwalu wciąż chroni go przed takim przyporządkowaniem. Przyzwyczajeni bowiem jesteśmy za właściwego twórcę filmu uznawać jego reżysera, czasem zwracamy uwagę na scenarzystę, oceniamy aktorów. Uświadomienie sobie roli operatora obrazu w filmie wiąże się $\mathrm{z}$ głębszą analizą. Twórcy festiwalu Camerimage starają się zmienić tę hierarchię i kierują nasze spojrzenie na określony aspekt filmu, którym jest obraz, jego wizualność, taki sposób przedstawienia danej historii, jaki tworzy właściwą atmosferę filmu. Autorzy zdjęć budują świat wizualny o określonej strukturze i logice. Tworzą rzeczywistość poprzez modelowanie światła, kadrowanie, inscenizację. Twórcy festiwalu tę umiejętność określają mianem sztuki, a dobry operator uznany zostaje za artystę. Nie pokuszę się o odpowiedź na pytanie, czym właściwie jest film, jaka jest jego natura i status, kto jest właściwym twórcą. Film jest dziełem złożonym, wynikiem wspólnej pracy wielu ludzi, dlatego trudno w prostej formułce wyrazić jego charakter. Wydaje się jednak, że praktykowana w Łodzi nobilitacja operatorów jest $\mathrm{w}$ pełni uzasadniona.

Teatr Wielki, w którym odbywają się najważniejsze projekcje, pęka w szwach od rana do północy; po dwunastej natomiast do rana integrująca ciasnota panuje w klubie festiwalowym w Hotelu Centrum. Kondy- 
cyjnie festiwal stanowi spore wyzwanie. Uczestnicy, profesjonaliści i studenci, tłumnie i z różnych stron świata przybywający na tę ucztę starają się dzielnie i wytrwale temu wyzwaniu sprostać. Camerimage cieszy się największą, z polskich festiwali filmowych, renomą na arenie międzynarodowej, może też poszczycić się obecnością wielu znakomitych i zasłużonych twórców kina. Niektórzy przyjeżdżają po to, by odebrać jedną z nagród, których z roku na rok przyznaje się w Łodzi coraz więcej; wielu jednak zostaje dłużej, aktywnie angażując się w życie festiwalowe. W tym roku Łódź gościła między innymi Alana Parkera, Olivera Stone’a, Vilmosa Zsigmonda, Toma Sterna, Kazimierza Karabasza, Andrzeja Żuławskiego...; zbyt wiele indywidualności, by wszystkich wymienić lub do tej wyliczanki odpowiednio wyselekcjonować. Zasługą festiwalu są warsztaty dla studentów prowadzone przez wybitnych twórców oraz spotkania i wywiady organizowane po każdym niemal pokazie filmowym. I choć festiwalowi nie brakuje elementów zdających się polegać wyłącznie na celebracji własnego rzemiosła, warto dostrzec, że festiwal to przede wszystkim miejsce spotkania ludzi oddanych jednej pasji, miejsce, które umożliwia im wzajemną wymianę opinii i doświadczeń. Różnorodność gatunkowa i tematyczna prezentowanych na festiwalu filmów jest olbrzymia i zdolna zaspokoić chyba wszelkie oczekiwania, bo repertuar z każdym rokiem poszerza się coraz bardziej. Filmy prezentowane są w następujących blokach: Konkurs Główny, gdzie walka toczy się o najważniejsze nagrody festiwalu, nagrody dla autorów zdjęć filmowych, Złotą, Srebrną i Brązową Żabę. Konkurs Etiud Studenckich, w którym zwycięzcy otrzymują Złotą, Srebrną lub Brązową Kijankę. Konkurs Filmów Polskich, w którym honoruje się Złotą Żabą jeden najlepszy, zdaniem jury, film roku, i wreszcie Konkurs Filmów Dokumentalnych, który w tym roku pojawił się na festiwalu po raz pierwszy. Tu także wybierany jest jeden film odznaczający się najlepszymi zdjęciami i nagradzany Złotą Żabą. Pojawił się też niedawno Konkurs Nokia Mobile Movie Competition, hołdujący współczesnym technologiom i Konkurs Wideoklipów. Obok pokazów konkursowych funkcjonuje obszerny blok pokazów specjalnych oraz pokazów retrospektywnych.

Nagradzanie w Łodzi nie ma końca, co bez wątpienia czyni festiwal niezwykle radosną uroczystością. Przyjemne bywa też oglądanie filmów, choć repertuar jest olbrzymi, przez co wybór staje się czasami trudny. Te rozterki i związane $z$ nimi rozczarowania lub zadowolenia to, poza fizycznym zmęczeniem, chyba jedyne niedogodności tygodnia festiwalowego. W tym roku, dość szczęśliwie, intuicja doprowadziła mnie na pokazy filmów nagrodzonych.

Slumdog. Milioner z ulicy Danny'ego Boyle'a ze zdjęciami Anthony'ego Dod Mantle zwyciężył w tym roku w Konkursie Głównym, otrzymując Złotą Żabę. Ten werdykt jury wydaje się potwierdzać wybór publiczno- 
ści, która po pokazie tego filmu klaskała najdłużej i najgłośniej. Nie jest bez znaczenia, że to chyba jedyny film konkursowy opowiedziany lekko i z poczuciem humoru, a na dodatek taki, w którym nie poskąpiono widzom pozytywnego zakończenia. Nie można tego nie doceniać. Trudno bowiem nie zauważyć (wrażliwsi dotkliwie mogą to odczuć) tendencji zwyciężającej od kilku lat na festiwalu, która polega na zdecydowanej przewadze filmów trudnych w odbiorze, podejmujących tematy zbrodni, terroryzmu, wojny, krzywdy ludzkiej. Twórcy przyglądają się i rejestrują cierpienie, rozkład człowieka i świata. Zbyt wiele $\mathrm{w}$ tym kinie okrucieństwa, bolesnego realizmu lub też nadmiernego patosu i szalejącego intelektualizmu. Skąd ta tendencja? Przecież przekraczanie granic praktykowane jest już wystarczająco długo i intensywnie, by wyczerpać swoją żywotność, a duch nowoczesny tak świadomy różnorodności i zmienności świata mógłby na podstawie swoich założeń odznaczać się dystansem i chłodną ironią. Być może zbliżamy się jednak do momentu przełomu, kiedy to jeden dyskurs ulega wyczerpaniu (ten postmodernistyczny, postnowoczesny), a drugi (osobiście bardzo bym chciała, by polegał na twórczym powrocie do źródeł antycznych) jeszcze nie znalazł dla siebie wyrazu, jeszcze się nie ukonstytuował.

W tym roku na festiwalu nie zabrakło filmów skupionych na tematyce wojennej. Miałam na przykład nieprzyjemność obejrzeć Rezolucje 819, film ważny ze względu na poruszany w nim temat - wojnę w Bośni, masakrę cywilnej ludności w Srebrenicy. Obraz jednak zupełnie nieudany, konstrukcyjnie i realizacyjnie zbliżony do telewizyjnego reportażu, emocjonalnie upośledzony $\mathrm{w}$ przedstawianiu tragedii, bez wyczucia, na dodatek nieszczęśliwie urozmaicony historią miłosną. Wiosna 1941, to z kolei polsko-izraelska koprodukcja, adaptacja opowiadania Idy Fink, próba przedstawienia losów kobiety ocalałej z Holocaustu. Dla mnie to głównie bardzo dotkliwa i drobiazgowa ilustracja tajemniczo umotywowanego romansu męża owej kobiety z Polką udzielającą im schronienia. Olbrzymie nagromadzenie emocji w nieuporządkowanej historii, z niewyjaśnionych przyczyn poszatkowanej podróżami do przyszłości, bo opowiadanej z perspektywy czasów powojennych. O II wojnie światowej jest także głośny film Kobiety $w$ Berlinie, ekranizacja wydanych anonimowo dzienników opisujących to, co spotkało tysiące kobiet po wkroczeniu żołnierzy radzieckich do Berlina. Wstrząsająca historia przemieniona $\mathrm{w}$ uładzoną, prostą i powierzchowną opowieść o romantycznym uczuciu rozkwitającym pomiędzy Niemką i wrażliwym Rosjaninem. Chłopiec w pasiastej piżamie, kolejny film o II wojnie światowej. Opowieść o chłopcu, który napotyka dookoła siebie zło i go nie rozpoznaje, a to, co widzi (obóz koncentracyjny) i czego nie rozumie tłumaczy poprzez odniesienia do dobra, bo tylko je zna. Scenariusz i przekonująca gra aktorska (szczególnie młodych chłopców) sprawiły, że jest to poru- 
szająca opowieść o dzieciństwie, niewinności, ufności, a także złu, które się w tym świecie pojawia.

Srebrną Żabę w Konkursie Głównym Plus Camerimage 2008 przyznano Cesarowi Charlone za zdjęcia do filmu Miasto Ślepców. Charlone to wybitny operator, nagrodzony już na festiwalu Camerimage w 2003 roku Złotą Żabą za film Miasto Boga w reżyserii Fernando Meirellesa. Miasto Ślepców to adaptacja prozy Jose Saramago także wyreżyserowana przez Fernando Meirellesa. Brutalna opowieść o ludziach, którzy znaleźli się w szczególnych okolicznościach. Bohaterowie niespodziewanie pozbawieni podstawowych umiejętności, stali się bezbronni niczym małe dzieci. Na ekranie pojawiają się krańcowe emocje, ujawniają kontrastowe postawy. Niewątpliwym atutem filmu są sugestywne, wypełnione bielą i światłem zdjęcia. Stanowią interesujący eksperyment formalny. Autor zdjęć mógł pozwolić sobie na pewną autonomiczność obrazu, ponieważ jego zadaniem nie było tylko opowiedzenie historii, ale ukazanie wagi zmysłu wzroku. Kamera konsekwentnie wprowadza w nierealną, a jednocześnie przerażająco rzeczywistą przestrzeń. Film prezentuje, moim zdaniem, w sposób spójny i skończony pewną rzeczywistość, której kruchość zaskakuje, ale i zatrważa.

Brązową Żabę na tegorocznym festiwalu Plus Camerimage przyznano Rainerowi Klausmannowi za zdjęcia do filmu Der Baader Meinhof Komplex. Nie podzielam lub też nie doceniam zachwytów wyrażanych nad filmem i jego stroną zdjęciową. Nużąco przedstawiona historia, ujęta w formułę aż nazbyt przypominającą kronikę historyczną skłoniła mnie do opuszczenia, bez cienia żalu, sali przed końcem projekcji. Interesującą, choć nienagrodzoną pozycją konkursową był Tulpan w reżyserii Sergeia Dvortsevoya, ze zdjęciami Jolanty Dylewskiej. Proste kino, sprawiające wrażenie lekko fabularyzowanej, dokumentalnej opowieści o życiu na kazachskim stepie. Skromna, ale niepozbawiona uroku historia Asy starającego się o ożenek z Tulpan, córką pasterzy. Film wypełniają liczne, moim zdaniem, zupełnie wyjątkowe przez swój naturalizm i świeżość sceny (wiele jest długich jednoujęciowych), które wyglądają, jakby zostały przypadkowo zarejestrowane lub podglądnięte. Co ciekawe, z informacji udzielonych przez twórców na konferencji prasowej wiadomo, że film w najdrobniejszych szczegółach został zaplanowany i wyreżyserowany.

Niezwykłym, polskim filmem pokazywanym na festiwalu w Konkursie Głównym były wyreżyserowane przez Jerzego Skolimowskiego, a sfotografowane przez Adama Sikorę Cztery noce z Annq. Artur Steranko i Kinga Preis odgrywają swoje role nie tylko bez zarzutu, ale w sposób do bólu przekonujący. Historia przedstawiona w filmie nie jest prosta ani przyjemna, a wykreowany świat wydaje się szorstki i brudny, bohaterowie są dotkliwie doświadczani przez życie. Jednocześnie jednak 
Skolimowski w niezwykle subtelny sposób pokazał to, co w świecie i w ludziach jest najdelikatniejsze i najpiękniejsze. Uważam, że stworzył dzieło wyjątkowe. Zdjęcia A. Sikory - malarskie i pastelowe - wprowadzają elementy nierealności do przedstawionej rzeczywistości.

Festiwal Camerimage to także środowe pokazy etiud studenckich. Trudno ująć w skąpym opisie różnorodność tematów, rozwiązań formalnych prezentowanych w tym obszernym bloku filmów (wyświetlono 31 etiud). Dominowały produkcje, w których niezdecydowanie lub brak dystansu autorów do prezentowanych treści były aż nadto widoczne. Zdarzały się też jednak filmy zadziwiająco dojrzałe i pomimo zaskakująco niskich środków profesjonalnie zrealizowane. Polskie szkoły filmowe: Państwowa Wyższa Szkoła Filmowa, Telewizyjna i Teatralna z Łodzi i Katowicki Wydział Radia i Telewizji zwyczajowo prezentowały wysoki lub co najmniej przyzwoity poziom. Na przestrzeni ostatnich lat w toczonym zażarcie wyścigu o palmę pierwszeństwa w rankingu polskich szkół filmowych Katowicki Wydział niepostrzeżenie wysunął się na prowadzenie. Zaprezentowane w tym roku na festiwalu dwie etiudy z Katowic godnie reprezentowały uczelnię. Jedna z nich Kolejny dzień przykuła moją uwagę dojrzałymi, konsekwentnie zrealizowanymi zdjęciami. Dużą siłę wyrazu uzyskano przez skromne, ascetyczne kadry stroniące od łatwej atrakcyjności. Szlachetne światło i obraz służący historii świadczyły o zdolnościach autora, a subtelna kolorystyka (ujednolicone, monochromatyczne barwy) dopełniła całości.

Tygodnia spędzonego w Łodzi nie uważam za czas zmarnowany. Różnorodność i wielość pokazów pozwoliła przyglądać się kinu światowemu w szerokim kontekście. Najnowsze produkcje, zarówno te większe, popularne, jak i te niszowe można było na bieżąco zestawiać i porównywać. 